\title{
Política, representaciones, redes y tránsitos. Aportes para el estudio de los Andes meridionales (siglos XV-XX)
}

\section{Politics, representations, networks and transits. Contributions for the study of the Southern Andes (15-20th centuries)}

\author{
Soledad González Díaz ${ }^{1}$ https://orcid.org/0000-0001-6530-5364 \\ ${ }^{1}$ Investigadora Centro de Estudios Históricos,Universidad Bernardo O’Higgins. Santiago, \\ CHILE. Email: horrorflorido@gmail.com
}

El presente volumen especial integra doce artículos centrados en los Andes meridionales, abarcando un amplio período que va desde la segunda mitad del siglo XV hasta la primera mitad del XX. Su objetivo es aportar nuevas perspectivas y antecedentes a temas que, si bien ya han sido explorados en el contexto de los estudios andinos, están lejos de agotarse en tanto problemas de investigación. Los artículos se han agrupado en torno a cuatro ejes fundamentales: política, representaciones, redes y tránsitos.

La primera parte, dispuesta en torno al tema Política, reúne dos obras capitales en el contexto de la articulación del dominio colonial en los Andes en la segunda mitad del siglo XVI. Germán Morong y Víctor Brangier, revisando el Gobierno del Perú de Juan de Matienzo, argumentan que su autor recuperó instituciones incaicas destinadas al control de la población con el fin de aplicarlas en el nuevo diseño gubernamental proyectado desde la Audiencia de Charcas. Soledad González y Joaquín Zuleta, en tanto, profundizan en la argumentación de la Historia índica de Pedro Sarmiento de Gamboa, ofreciendo un análisis textual basado en el único manuscrito de la obra, examinando los rasgos que definen la tiranía de los incas y privilegiando un enfoque interdisciplinario que congrega a la filología y la etnohistoria.

La segunda parte, dedicada al eje Representaciones, la integran cuatro artículos. El denominador común de todos ellos es que abordan la construcción de autorías, vínculos o prejuicios, partiendo de imágenes o relatos. Paula Martínez y Alberto Díaz exploran la relación entre las cofradías de indios en el Cusco y la ejecución de las pinturas murales que tuvieron como tema central las postrimerías en los siglos XVI y XVII, proponiendo que el programa iconográfico que éstas transmitieron sugiere una autoría indígena o mestiza. Marco Antonio Arenas, Bosco González y José Luis Martínez, por su parte, identifican, comparan y analizan los sitios con arte rupestre colonial en los corregimientos de Tarapacá y Atacama, relevando la importancia de los "espacios discretos", es decir, lugares alejados de las reducciones o pueblos de indios y que, a la par de las redes viales, albergan un importante registro visual.

Patricio Ibarra identifica los prejuicios racistas y nacionalistas que subyacieron al conflicto armado de la Guerra del Pacífico, adentrándose en las crónicas y 
documentos personales de los chilenos que participaron en la expedición a Bolivia y Perú, es decir, en la mirada íntima de sus propios protagonistas. Rodrigo Ruz, Luis Galdames y Michel Meza, en la misma línea, documentan el espacio de deshumanización que, tras el conflicto, abrió la nueva frontera, evidenciando la forma en que los reportajes gráficos de las revistas Zig-Zag y Sucesos estigmatizaron a los también nuevos vecinos.

La tercera parte, estructurada en torno al tópico Redes, analiza la configuración de redes de poder y redes familiares, tanto reales como imaginadas. Luis Miguel Glave y Alberto Díaz, teniendo como hilo conductor la visita del licenciado Diego Briviesca de Muñatones a la Audiencia de Lima, cartografían las áreas de influencia del primer encomendero de Tarapacá, Lucas Martínez Vegazo, profundizando en los distintos niveles de su entramado de influencias. Nelson Castro demuestra cómo los miembros de la élite indígena charqueńa, dos siglos más tarde, construyeron una comunidad de memoria y una red de sociabilidad en torno a las figuras de Tito Alonso Atauchi o de Viracocha Inca, examinando y comparando un extenso corpus documental proveniente de diversos archivos. Xochitl Inostroza, por último, ahonda en las dimensiones sociales, políticas y simbólicas de las redes de parentesco estructuradas en torno al rito del bautizo, a través del análisis de los libros de la parroquia de Belén, en el actual norte de Chile, a fines del siglo XVIII y principios del XIX.

La cuarta y última parte de este volumen se articula en torno al concepto de Tránsitos, tanto en su dimensión material como temporal. Simón Urbina, Mauricio Uribe, Carolina Agüero y Colleen Zori reconstruyen el tránsito del período Tardío al Colonial Temprano en la zona de Tarapacá, integrando registros arqueológicos y documentación etnohistórica. Carolina Odone examina los contextos de producción y circulación de qeros, aquillas y matis en el espacio surandino en los siglos XVI y XVII, basándose en la información contenida principalmente en testamentos indígenas. Jorge Hidalgo, Priscilla Cisternas y Julio Aguilar, para terminar, ofrecen un panorama documentado de las transformaciones ligadas a la pesca y extracción de guano en la costa de Arica y Tarapacá, desde una perspectiva etnohistórica que apuesta por un análisis de larga duración, desde los siglos XVI al XIX.

En la medida en que todos los artículos son el resultado de diferentes proyectos de investigación, esperamos que la originalidad de la evidencia y las metodologías de análisis contribuyan a abrir nuevos espacios de diálogo y debate, ampliando el horizonte de las investigaciones sobre las transformaciones políticas y sociales en los Andes meridionales. 